\title{
Determinants of Customer Satisfaction and its impact on Customer loyalty in Nokia brand
}

\author{
Muhammad Rizwan (Corresponding author) \\ Lecturer, Department of Management Sciences, \\ The Islamia University of Bahawalpur, Pakistan \\ E-mail: rizwan.arshad@iub.edu.pk
}

Muhammad Abu Umair

Department of Management Sciences, The Islamia University of Bahawalpur, Pakistan

Anser Fiaz

Department of Management Sciences, The Islamia University of Bahawalpur, Pakistan

Qasim Rashid

Department of Management Sciences, The Islamia University of Bahawalpur, Pakistan

Doi:10.5296/ jsr.v5i1.6574 URL: http://dx.doi.org/10.5296/ jsr.v5i1.6574

\begin{abstract}
This study examines major influences on customer loyalty in a research framework where customer loyalty is the dependent variable and customer satisfaction, perceived price, service quality and trust are all independent variables. The research also tests the hypothesis that there exists a moderating relationship between service quality and customer satisfaction. The study employs various statistical techniques, including reliability, factor and regression analysis. The epistemology of research was primarily qualitative and involved 170 citizens of Pakistan through a questionnaire led survey and factor analysis was further applied to confirm the results. This study acknowledges service quality positively affecting customer satisfaction with perceived price acting as a moderating variable. In addition to that service quality also has a significant positive influence on trust. Customer satisfaction is a strong variable effecting customer loyalty and trust positively. Therefore it could be postulated that customers with high rated perception of service quality and satisfaction also generally exhibit repurchase intent and strong loyalty towards the products. Furthermore, the study also adds
\end{abstract}


up that the moderating variables positively influence the relationship. Increase in the customer's perception on the reasonableness of price also tends to increase the impact of service quality on customer satisfaction.

Keywords: Customer Loyalty, Customer needs, Market, Pakistan

\section{Introduction}

Customer loyalty means making long-term relationship with customers. customer loyalty towards the brand where the customer has a positive set of acknowledged believe towards the brand which he has purchase and want to repurchase the brand. Loyalty is to some extent inner to the customer and it can only change through change in the value and thinking pattern of the customer. Pleased customers with the product/service are typically retain and they keep up their relationship with the supplier for longer period of time. When the satisfaction level of consumer decrease from their hope then the consumer want to change and seem to be for superior supplier.

Loyalty has been a main concern in marketing planning for different reasons including global competition, technological development, and customers awareness. In fact, a long success is not just a function of fair price but it is a function of quality of products and services and many corporation prefers to build a relationships with their customers forever using customer oriented preference. consumer loyalty creates a word of mouth which is helpful for organization. Thus, it is essential to increase and make customer loyal which may serves a main factor in long-term success of organization.

The most important issue organizations face today is customer loyalty. to Create customer loyal have become most important because increase in competition and due to change of market trend strongly after few days. The world move forward every day to satisfying customers to determining ways to make them loyal and the more significant piece of the current trade. The important strength for customers to become loyal with one supplier or decide to leave that and decide to purchase and repurchase from the one supplier. Loyalty can never be buy on the other hand and maintenance is the decision of the consumer to continue with his and her current supplier.

To create the customer loyalty the managers should be aware of what their customer's value in order to carry on and grow in highly competitive market. By knowing what consumer presently value is clearly not sufficient because what the value change suggest that suppliers must also have the capacity to foresee what consumer will value that why the change is significant according to consumer. There are strategies available for organization to manage their consumer loyalty programs increase consumer satisfaction or raise switching barriers. corporations can raise benefits ands they provide regular customer. Relational benefits, are the benefits consumers can gain from long-term relationships beyond the core service attributes that why customer loyalty is important. 
Customer loyalty can create through brand image. Brand image is described as the overall feelings make on the mind of the public on a firm which is associated to physical and behavioral attribute of the firm. It is a outcome of an aggregation process which incorporates with various information used by consumers to produced estimation of a firm. A good brand image have been found to help launch and keep loyal relationship with customers and control to buy again and again purchase.

\section{Literature Review}

\section{Customer loyalty}

Customer loyalty is customers objective to repurchase something base on his/her expectancy and the past experience. Customer loyalty is the mind-set that compels the customers to reuse a product and service or brand again and again (John, 2011). Customer loyalty can be create by identify the customer need, managing them and fulfill them Maiyaki et al. (2011). Companies can build up customers loyalty by offering better and admirable services or quality products. Customer loyalty is supposed to be the customer favorable attitude and there buying pattern. consumer loyalty and Consumer satisfaction are mutually consider as a device to build up and achieve sustainable spirited benefits. Loyal customers can be separated into two main categories that are Satisfied Consumers and Un-Satisfied Consumers. A strong association exists between the loyal and satisfied consumers.

Sometimes un-satisfied consumers are loyal due to their promise with dealers. Satisfied customers, on the other if require the commitment with the supplier; will always switch once when the competitor with better service is acknowledged. This is fake loyalty because of which the consumer feels hurdles during which stops him to prefer another supplier. These hurdles are called switching expenses. The consumer loyalty towards a company is mainly the consumer's feelings which compels him to reuse or buy again and again the product and service of that exacting company and the referring of that product and service by the consumer to the other of his family member, friends and others.

The consumers are loyal if they purchase the product/service over and over again and they also recommend to other people to attach with the corporation and its products and services for longer period of time. Some benefits of customer loyalty are that new consumer service expenditure is high than old consumer. Old customers are willing to give high price for particular product/service. A loyal customer perform as a resource of success for a corporation as it act as a agent for company`s marketing (Siddiqi, 2010). The sucess of any business/company depend upon the number of loyal consumers as they stay with the company and are involve in repurchase (Khokhar et al., 2011).

Customer loyalty is increased by different factors like by increasing customer service, increasing network quality and value added features increasing loyalty, ensure company's growth, thus marketing strategy should be planned in a way that they will be capable to maintain the accessible consumers (John, 2011).the company success will be depend on by providing best services and good quality obviously will helps in increasing customers loyalty and customer satisfaction. Making new clients is very tough and costly but on other hand it 
is very easy and inexpensive to retain existing consumers. Making loyal customer is very profitable and it has positive impact on the growth of company due to continuous purchase service/product of a for a longer period of time (Khokhar et al., 2011). Loyal consumer is very beneficial for company it will attach to the same company for long period of time and it is source for companies for creating development and profitability.

\section{Customer satisfaction}

Customer satisfaction is the extent of frequent buying of a product and service. Customer satisfaction create value for customer, in short supervision of their hopes and to fulfill their requirements (Guzzo, 2010). Consumer satisfaction is defined as meeting one`s criteria or satisfying one`s hopes or we can say that if customer is satisfied with product and services it has a different emotion or manners towards a particular brand it has used Maiyaki et al. (2011). They more explain Consumer satisfaction is one of the main goal of marketing action whereby it create relationship what consumers purchase and how they act.

It is clear that if anyone is satisfied with specific offer or product he will acquire themselves grip in repurchase. it is depend on Customer that how they identify the quality and service and customer satisfaction depend on quality(Ali et a 2010) .Satisfaction is a main determinant which effect the different variables and corporation's economic progress. Satisfaction come after use of some products or services which is essentially the result of actual and expected functions of product (Khokhar eal., 2011). For retting the customers it is very significant for any company to recognize and satisfy needs of customer that would help them for success. customer satisfaction is Most important objective for the marketing process. For high quality in their products and service; and most companies struggle as contests is increased for with a view to eventually growth in satisfying their consumers. Growth of any company depends on the specifics that they understands the needs of consumers and satisfy them in good manners. while every customer has different need, different attitudes and feelings, different behaviors, different satisfaction levels, different buying pattern, therefore it is not essential that every consumer get same level of satisfaction for specific products or services being presented. For this purpose it is necessary to have clear idea about what customer wants and what will give them maximum satisfaction (Maiyaki et al., 2011). Higher the customer satisfaction higher will be the customer loyalty toward company and more will be the continued continuation of business.

The strong relationship exists between management and marketing department. There is a positive direct, relationship between consumer loyalty, consumer satisfaction and product/service quality. (Ali et al., 2010). Loyal customer is directly related in maintaining a Higher customer satisfaction. service quality is the factor that link customer loyalty and customer satisfaction (Siddiqi, 2010; Iqbal et al., 2013).

H1: customer satisfaction has a positive influences on customer loyalty. 


\section{Product Quality}

Product quality is assessment of current expenditure experiences by the market serve. This build evaluate customization and consistency of a given product and service. Customization is the scale to which a product and service fulfill a consumer requirement, and consistency is the scale to which firm offer is consistent, identical, and free from deficiency. Product quality is accepted to contain a positive outcome on consumer satisfaction.

earlier research's suggest both a direct e.g., Boulding etal.,1993) and indirect (e.g., Woodruff, 1997) result of product quality on faithfulness.A elevated level of product quality over and over again engender feeling of joy, enthusiasm, and fulfilment It may advance customer assurance and belief in the brand and service. mainly when a customer assessment of the supposed performance of specific attribute of a product is superior than his or her previous expectation, this will outcome in solid purchaser loyalty (Parasuraman etal.,1988).

H2: Product quality has a influences on customer satisfaction.

\section{Service Quality}

Service quality can be clear by customer and that it occur when a service institute provide service that satisfy the customer's need (Metters et al). so we can say that, service quality is defined as the fulfillment of customer's hope. Service quality defined as a customer's belief or attitude concerning the rate of service superiority in environment (Ward et al).

Most experienced and successful business units in trade have realized that their success or failure factors would not merely depend on their existence on web or low price, but the important factor of transferring the high quality services has also a specific factor. . (Carna et al.2009). service quality can be described as customers' assessment of the process and result of interaction with an online seller. Service quality includes five dimensions including ease of usage, designing website, ordering, responding, and trust. Service quality refer to the scale of difference between customer normative hope for the services and their observation of service performance. Ribinik (2004).

According to (Fornell) High service quality guide to high level of customer maintenance which can constitute for profitability. It have been found that supposed service quality is positively linked with reuse purpose, suggestion and conflict to attract the better choices. According to (Anderson and Narus) faith is a belief on another party word and guarantee since the party is consider as important, sincere, honest, and capable to perform action that will cause in a specific positive outcome and prevent action that will stop in negative result. A buyer who belief on specific brand is good likely to form optimistic buying maintenance toward the brand. Service quality is a difficult to build which has multi-dimension and multi-facet attributes. To confirm the service quality there are so much research's are conducted in last few years. 
On the other hand, Parasuraman et al. (1985) conduct researches in a number of business sector to build up and purify a multiple-item instrument to measure customers' global evaluation of a company service quality. Their level occupied potential-perceptions gap score along five dimensions: consistency, reaction, guarantee, sympathy, and tangible (Metters et al., 2003). After Three years on, Parasuraman and his age group (1988) defined perceived service quality as "the consumer's judgment about the authority and brilliance of a product," If service provider gives the service on time as compared to another competitor then customer will be satisfied and more loyal compared to competitor. most customer retain with companies due to there high service quality.

H3: Service quality has a influences on customer satisfaction.

\section{Financial Benefit}

Financial Benefit is the economical benefits that customers get from cost saving(Garrette and Karnani, 2010). Customers will get financial benefits when the price of the product is lower than other competitors so they can save some money. The performance of these benefits can be in the form of special discounts as a reward, especially when customers buy in a big volume or when they buy products on a regular basis. Financial Benefit gives better price to its members. Financial Benefit gives special discounts to its members.

Financial Benefit allows members to exchange their points with the desired reward they want to retain or ignore the customer price is one of the major factor that can reason of customer satisfaction(Butt, 2011). Price is the means of substitute with which we get value, that can either in tangible (goods) and intangible service (Butt, 2011).for satisfaction customer is willing to give a smaller amount in as a result in other words we can say that less price is honestly associated to high degree of customer trust and high quality is related to high scale of consumer satisfaction. Satisfied customer pay extra price for product (Ali et al., $2010 \mathrm{a}, \mathrm{b}$ ). Customer`s choice to purchase service and product depend on two things. if the quality of the product according to the customers expectation then the customers willing to pay high price and must be positive about the brand. (Garrette and Karnani, 2010).

Customer satisfaction increases when costumers become loyal to the company, buy more than they use to be and repeatedly. Customers have more initiatives to maintain their relationships with the company so that it increases customer loyalty if they gets special discount( Kotler and Armstrong, 2004).It also include hard and soft benefit provide by the firm. Hard benefit are economic gain that Customer get while soft benefit relate to the customer's sense of 'special status' and appreciation going to the consumer usually, the longer a purchaser stays with a firm, the more benefit that are received thus engender loyalty.

If customer gets high quality products at low price and special discounts then the customer will be satisfied and create positive words of mouth. 
H4: Financial Benefit has a influences on customer satisfaction.

\section{Perceived value}

Perceived value is a kind of gain where a customer obtains in return for the paid cost(Gallarza $\&$ Sorae2006). Perceived value is a strategic instrument to attract and retain customers based on important factors for the success of industrial corporations and service providers. (Gallarza \& Sorae ).

When we purchase a product after using the product we will get the idea of cost put in and benefit of using a product determine the product life, get the idea which will persuade customers' purchase objective and behavior. Consumer compared benefit received with cost in order to compare with competitors. When supposed value meets the need and want of the customer then customer feel value and want to reuse the product. When the supposed value is less than the expectation then the customer loyalty is decreased.

Product quality is measured when we use the product comparative to the price paid by customer. Perceived value is the evaluation of the price paid for the excellence. Quality is measured in term of the product efficiency. Perceived value arrangement provide an chance for contrast of the firms according their price-value ratio. In the model, perceived value is expected to has a positive impact on satisfaction. There are different definitions of definition of perceived value be present but the definition of Zeithaml (1988,) is the best definition most commonly accepted perceived value in the literature of tradeoff. it is tough to determine difficult nature of perceived due to the uni-dimensional conceptualization policy is efficient and basic, but it cannot the value. As noted by Sweeney and Soutar (2001), "for understanding that how customers value products and services a complicated measure is required'. In an integrative approach, it is important to understand the value concept, if anyone can understand a given type of value only by in view of its relationship to various types of value (Holbrook, 1999).

Earlier period research suggest that perceived value as simply a tradeoff between quality and price is not enough to achieve competitive advantage (Rintamaki et al., 2006. Al-Sabbahy et al (2004) one item cannot clarify the concept of seeming value. Thus, a number of researchers argue that perceived value is more multifarious that a multi-dimensional approach of value perception should be measured by scholar and manager, and that customer choice is the result of more then one value observation (e.g. Petrick,

2002). If customer gets the benefit equal to the cost paid then customer will be satisfied and want to Repurchase the product. If customer do not gets the benefit equal to the cost paid then customer will be dissatisfied and want to churn from one product to another.

H5: Perceived value has a influences on customer satisfaction. 


\section{Research Methodology}

The current research is descriptive in its nature. Descriptive research can be explain as telling something, some phenomenon and any particular situation. Descriptive researches are those researches that describe the accessible situation instead of interpret and making judgment (creswell 1994). The main goal of the descriptive research is confirmation of the develop hypothesis that reflect the current situation. This type of research provide information about the current situation.

\section{Sample/ data}

In order to collect the data for understanding the situation about the customer loyalty ,a sample of 150 respondents will ask to contribute in a self-adminsterdquestionnaire.the current study utilize a non-probability sampling technique that is convenience sampling. convenience sampling is a sampling technique that obtains and collect the relevant information from the sample or the unit of study that are conveniently available(Zikmund,1997).convenience sampling is normally used for collecting a large number of completed surveys speedily and with economy(Lym et al.2010).

We select these sample members from organization of Bahawalpur. Main clusters will target to collect the sample data from students, the islamia university of Bahawalpur.

\section{Instrument and measure}

The survey instrument of the current study address two major purpose: first is to analyze the relationship of different variables of customer loyalty. Second, to collect information about different characteristics of the respondents that can be used to understand the variations in different category.

The survey instrument contains two sections. It includes different personal demographic variables. This section will obtain the respondent's information about gender, age, income, education and status.

The latent variables that are important in the current study include customer loyalty, customer satisfaction, product quality, perceived value, financial benefits service quality. This section of the study is developed based on the past literature and questionnaire.

The scales of the study were adopted from the previous literature and published studies. The first variable was customer loyalty has five items and that scales were taken from (Grewal \& Levy 2010). The second variable was customer satisfaction having two items and these scales were taken from (Dick \& Basu 1994).

The third variable was product quality having four items and these scales were taken from (Boulding et al 1993, Woodruff 1997). Next variable was perceived value and financial benefits having three items and these scales were taken from (Gallarza \& Sorae,2006).the other variable was service quality support having five items and these scales were taken from (Ouyang,2010 Santos,2003 Ward et al,2009). 
Table1: scales of the study:

\begin{tabular}{|c|c|c|c|}
\hline $\begin{array}{l}\mathbf{S r} \\
\#\end{array}$ & Variable & Items & Reference \\
\hline 1 & $\begin{array}{l}\text { Customer } \\
\text { loyalty }\end{array}$ & $\begin{array}{l}\text { 1-I shall continue with this brand in the next few } \\
\text { years. } \\
\text { 2-If I had to contract the service again. I would } \\
\text { choose my operating brand again. } \\
\text { 3- I consider myself to be loyal to my operating } \\
\text { brand. } \\
\text { 4- To me, my operating brand is clearly the best } \\
\text { brand on the market. } \\
\text { 5- I would recommend my brand if somebody } \\
\text { asked my advice. }\end{array}$ & $\begin{array}{l}\text { (Grewal \& } \\
\text { Levy 2010) }\end{array}$ \\
\hline 2 & $\begin{array}{l}\text { Customer } \\
\text { satisfaction }\end{array}$ & $\begin{array}{l}\text { 1- Over all I am satisfy with specific experience } \\
\text { with the brand. } \\
\text { 2- I am satisfy with my decision to purchase } \\
\text { from this brand. }\end{array}$ & $\begin{array}{l}\text { (Dick \& Basu } \\
\text { 1994) }\end{array}$ \\
\hline 3 & Product quality & $\begin{array}{l}\text { 1-This brand is of high quality. } \\
\text { 2-It is likely that the brand is very high quality. } \\
\text { 3- It is likely that brand is of very consistent } \\
\text { quality. } \\
\text { 4- It is likely that the brand offer excellent } \\
\text { features. }\end{array}$ & $\begin{array}{l}\text { (Boulding et al } \\
\text { 1993, Woodruff } \\
1997 \text { ) }\end{array}$ \\
\hline 4 & Perceived value & $\begin{array}{l}\text { 1-The brand has a good value for money. } \\
\text { 2-The brand provides good services for money. } \\
\text { 3-The brand provides extra services for money. }\end{array}$ & $\begin{array}{l}\text { (Gallarza \& } \\
\text { Sorae,2006) }\end{array}$ \\
\hline 5 & Financial & 1-The brand provides a special discount. & (Kotler \& \\
\hline
\end{tabular}




\begin{tabular}{|l|l|l|l|}
\hline benefits & $\begin{array}{l}\text { 2- The brand provides reward program for } \\
\text { customer. } \\
\text { 3-The brand has a better price for customer. }\end{array}$ & $\begin{array}{l}\text { Armstrong } \\
\text { 2004) }\end{array}$ \\
\hline Service quality & $\begin{array}{l}\text { 1-The brand has a various feature and function. } \\
\text { 2-The brand provides website information. } \\
\text { 3-The brand provides full information about } \\
\text { feature of product and fulfilling commitments } \\
\text { for customer. } \\
\text { 4-The brand providing service for customer as } \\
\text { soon as possible. } \\
\text { 5-The brand providing the customer with clear } \\
\text { Wantos,2003 } \\
\text { information about transaction. }\end{array}$ \\
\hline
\end{tabular}

\section{Procedure}

The questionnaire was distributed among 150 respondent in Bahawalpur. These respondent are selected based on the criteria above mentioned. Before giving the questionnaire, the purpose of study and questions were explained to the respondents so they can easily fill the questionnaire will relevant responses. A total of 150 questionnaire were selected. After collecting the completed questionnaires, these questionnaires were coded and entered into spss sheet for further analysis.

\section{Reliability analysis}

Table 2

Reliability of measuring instrument

\begin{tabular}{|l|l|l|}
\hline Scales & Items & Cronbach alpha \\
\hline Customer loyalty & 5 & 0.683 \\
Customer satisfaction & 2 & 0.562 \\
Product quality & 4 & 0.753 \\
Perceived value & 3 & 0.693 \\
Financial benefits & 3 & 0.616 \\
Service quality & 5 & 0.711 \\
\hline
\end{tabular}




\section{Results and analysis}

Personal and demographic information such as gender, age, income, education and company are presented in the following table.

\begin{tabular}{|c|c|c|c|}
\hline Variables & Category & Frequency & Percentage \\
\hline Gender & $\begin{array}{l}\text { Male } \\
\text { Female }\end{array}$ & $\begin{array}{l}98 \\
52\end{array}$ & $\begin{array}{l}65.3 \\
34.7\end{array}$ \\
\hline Age & $\begin{array}{l}\text { 15-20 years } \\
20-25 \text { years } \\
25-30 \text { years } \\
30-35 \text { years } \\
35-40 \text { years }\end{array}$ & $\begin{array}{l}50 \\
82 \\
8 \\
6 \\
4\end{array}$ & $\begin{array}{l}33.3 \\
54.7 \\
5.3 \\
4 \\
2.7\end{array}$ \\
\hline Income(Rs/month) & $\begin{array}{l}\text { Below } 15000 \\
15000-35000 \\
35000-40000 \\
\text { Above } 40000\end{array}$ & $\begin{array}{l}85 \\
28 \\
13 \\
24\end{array}$ & $\begin{array}{l}56.7 \\
18.7 \\
8.7 \\
16\end{array}$ \\
\hline Education & $\begin{array}{l}\text { Matriculation } \\
\text { Inter } \\
\text { Bachelor } \\
\text { Master } \\
\text { MS }\end{array}$ & $\begin{array}{l}6 \\
16 \\
76 \\
39 \\
13\end{array}$ & $\begin{array}{l}4 \\
10.7 \\
50.7 \\
26 \\
8.7\end{array}$ \\
\hline Status & $\begin{array}{l}\text { Student } \\
\text { Employed } \\
\text { Businessman }\end{array}$ & $\begin{array}{l}127 \\
8 \\
5\end{array}$ & $\begin{array}{l}84.7 \\
5.3 \\
3.3\end{array}$ \\
\hline
\end{tabular}




\begin{tabular}{|l|l|l|l|}
\hline & Unemployed & 3 & 2 \\
Housewife & 7 & 4.7 \\
\hline
\end{tabular}

Hypothesis testing

\section{H1: customer satisfaction and customer loyalty}

According to the outcome of the study, the variable customer satisfaction and customer loyalty has significant and positive relationship with $(\beta=.546)$ and significance value $(p<0.000)$ that means the customer satisfaction contribute $54 \%$ to customer loyalty. Result of the current study validate the $\mathrm{H} 1$.

\section{H2: product quality and customer satisfaction.}

The regression outcome of the study conform the significant positive relation between product quality and customer satisfaction with $(\beta=0.386)$ and $(\mathrm{p}<0.000)$.product quality contributes $39 \%$ to customer satisfaction. the current study validate the $\mathrm{H} 2$.

\section{H3: perceived value and customer satisfaction.}

The analysis shows perceived value has insignificant relationship with customer satisfaction with $(\beta=0.123)$ and $(p>0.196)$.perceived value contribute $13 \%$ to customer satisfaction. it reject the $\mathrm{H} 3$.

\section{H4: financial benefit and customer satisfaction}

Regression estimates results shows that financial benefit has insignificant relationship with customer satisfaction with $(\beta=0.009)$ and $(p>0.911)$.it means the financial benefits contribute $9 \%$ to customer satisfaction. the $\mathrm{H} 4$ is rejected.

\section{H5: service quality and customer satisfaction.}

The regression analysis results shows that service quality role has insignificant relation with customer satisfaction with a $(\beta=0.139)$ and $(p>.153)$. it means the service quality contribute $14 \%$ to customer satisfaction. the outcome reject the hypothesis H5. 


\begin{tabular}{|c|c|c|c|c|c|c|}
\hline Hypothesis & Model variables & Estimate & S.E & C.R & $\mathrm{P}$ & Results \\
\hline HI & $\begin{array}{l}\text { Customer } \\
\text { customer loyalty }\end{array}$ & .546 & .063 & 7.920 & 0.000 & supported \\
\hline $\mathrm{H} 2$ & $\begin{array}{l}\text { product quality } \overrightarrow{c u s t o m e r} \\
\text { satisfaction }\end{array}$ & .386 & .088 & 4.063 & 0.000 & Supported \\
\hline H3 & $\begin{array}{l}\text { perceived } \longrightarrow \text { value } \\
\text { customer satisfaction }\end{array}$ & .123 & .084 & 1.299 & 0.196 & $\begin{array}{l}\text { Not } \\
\text { Supported }\end{array}$ \\
\hline $\mathrm{H} 4$ & $\begin{array}{c}\text { Financial } \\
\text { customer }\end{array} \longrightarrow$ benefit & .009 & .074 & .112 & 0.911 & $\begin{array}{l}\text { Not } \\
\text { Supported }\end{array}$ \\
\hline H5 & $\begin{array}{l}\text { Satisfaction } \\
\text { Service quality ctrstomer } \\
\text { Satisfaction }\end{array}$ & .139 & .101 & 1.438 & 0.153 & $\begin{array}{l}\text { Not } \\
\text { Supported }\end{array}$ \\
\hline
\end{tabular}

\section{Discussion}

One of the key contributions of this model was to provide a better understanding of how customer loyalty affects different variables. these study model posited that customer loyalty arises from customer satisfaction, product quality, perceived value, financial benefits and service quality. The results suggest that each of these factors influence the customer loyalty to different degrees. In most cases support was found for many, with all of the direct effects. to increase customer loyalty organization should focus on customer satisfaction, product quality, perceived value, financial benefits and service quality . depend on the conclusion of this study, it means that product quality and customer satisfaction are positively related to customer loyalty towards nokia brand in pakistan. As a issue of information service quality, perceived value and financial benefit has also a impact on customer loyalty. This means that when the product quality is increased then customer satisfaction is also increased and customer will be loyal and customer loyalty increased and the overall customer loyalty of the nokia brand will increase. their commitment to repeat to repurchase the product in the future. 


\section{Reference}

[1] Bitner, M. J., \&Hubbert, A. R. (1994). Encounter satisfaction versus overall satisfactionversus quality. In R. T. Rust, \& R. L. Oliver (Eds.), Service quality: New directions intheory and practice (pp. 72-94). Thousand Oaks, CA: Sage.

[2] Gwinner, K.P., Gremler, D.D., Bitner, M.J., 1998. Relational benefits in services industries: the customer's perspective. Journal of the Academy of Marketing Science 26, 101-114.

[3] Hennig-Thurau, T., Gwinner, K.P., Gremler, D.D., 2002. Understanding relationship marketing outcomes: an integration of relational benefits and relationship quality. Journal of Service Research 4, 230-247.

[4] Flint, D. J. (2004). Strategic marketing in global supply chains: Four challenges. Industrial Marketing Management, 33(1), 45-50.

[5] Oliver, R. L. (1980). A cognitive model of the antecedents and consequences of satisfaction decisions. Journal of Marketing Research, 17(4), 460-469

[6] Oliver, R. L. (1999). Whence consumer loyalty? Journal of Marketing, 63(4), 33-44.

[7] Rust, R. T., \& Oliver, R. L. (1994). Service quality: New directions in theory and practice. Thousand Oaks, CA: Sage.

[8] Bitner, M.J., 1995. Building service relationships: it's all about promises. Journal ofthe Academy of Marketing Science 23 (Fall), 246-251.

[9] Berry, L.L., 1995. Relationship marketing of service: growing interest, emerging perspectives. Journal of the Academy of Marketing Science 23 (4), 236-245.

[10] Barlow, R.G., 1992. Relationship marketing: the ultimate in customer services. 
Retail Control March 29-37

[11] Crosby, L.A., 1991. Building and maintaining quality in the service relationship.

[12] Gro“ nroos, C., 1994. From marketing mix to relationship marketing: towards a paradigm shift in marketing. Management Decision 32 (2), 4-20.

[13] Morgan, R. M., \& Hunt, S. D. (1994). The commitment-trust theory of relationshipmarketing.Journal of Marketing, 58(3), 20-38.

[14] Czepiel, J.A., 1990. Service encounters and service relationships: implications for research. Journal of Business Research 20 (1), 13-21.

[15]Parasuraman,A.,Berry,L.L.,Zeithaml,V.A.,1988.SERVQUAL:amultiple-itemscale for measuringconsumerperceptionsofservicequality.JournalofRetailing64 (1), 12-40.

[16] Slater, S. F., \&Narver, J. C. (2000). Intelligence generation and superior customer value.Journal of the Academy of Marketing Science, 28(1), 120-127

[17] Woodruff, R.B.,1997.Customervalue:thenextsourceofcompetitiveadvantage. Journal oftheAcademyofMarketingScience25(2),139-164. Y.

[18]Flint, D. J., Woodruff, R. B., \&Gardial, S. F. (2002). Exploring the phenomenon of customers' desired value change in a business-to-business context. Journal of Marketing, 66(4), 102-117.

[19] Akhter, W., Abbasi, A.S., Ali, L. \&Afzal, H. (2011). Factors affecting customer loyalty in Pakistan.African Journal of Business Management, 5(4), 1167-1174.

[20]Reichheld, F. F. (1996). The Loyalty Effect: the Hidden Force behind Growth, Profits, and Lasting Value. Boston,

MA: Harvard Business School Press.

[21]Fornell, C. (1992). A national customer satisfaction barometer: The Swedish experience. 
Journal of Marketing,56(1), 6-12. http://dx.doi.org/10.2307/1252129

[22] Aydin, S., Ozer, G., \&Arasil O. (2005). Customer loyalty and the effect of switching costs as a moderator variable: A case in the Turkish mobile phone market. Marketing Intelligence \& Planning,23(1), 89-103

[23] Matt Hasan (2001), "The importance of customer retention ", Proceedings of the Marketing in a Global Economy Conference, Buenos Aires, pp. 215-224.

[24]Morgan, R.M., Hunt, S.D., 1994. The commitment-trust theory of relationship marketing. Journal of Marketing 58 (July), 20-38.

[25] Anderson, E., \&Weitz, B. (1989). Determinants of continuity in conventional industrialchannel dyads.Marketing Science, 8(3), 10-23.

[26]Berry, L. L. (1995). Relationship marketing of services: Growing interest, emergingperspectives. Journal of the Academy of Marketing Science, 23(4), 236-245.

[27] Crosby, L. A., Evans, K. R.,\&Cowles, D. (1990). Relationship quality in services selling: An interpersonal influence perspective. Journal of Marketing, 54(3), 68-81.

[28]Hennig-Thurau, T., \& Klee, A. (1997). The impact of customer satisfaction and relationship quality on customer retention: A critical reassessment and model development. Psychology and Marketing, 14(8), 737-764.

[29] Yousafzai, S.Y., Pallister, J.G., and Foxall, G.R. (2003), "A proposed model of e-trust for electronic banking", Technovation, Vol. 23 No. 11, pp. 847-860.

[30] Mayer, R.C., Davis, J.H. and Schoorman, F.D. (1995). "An integratif model of organizational trust", Academy of Management Review, Vol. 30 No. 3, pp. 709-734

[31] Ndubisi, O.N. (2007). Relationship Marketing and Customer Loyalty, Marketing Intelligence \& Planning, 25(1), 98-106. 


\section{Macrothink}

Journal of Sociological Research

ISSN 1948-5468

2014, Vol. 5, No. 1

[32] Spreng, R. A., MacKenzie, S. B., \&Olshavski, R. W. (1996). A reexamination of the determinants of consumer satisfaction. Journal of Marketing, 60(3), 15-32.

[33] Rauyruen, P., \& Miller, K. E. (2007). Relationship quality as a predictor of B2B customer loyalty.Journal of Business Research, 60(1), 21-31

[34]Roberts, K., Varki, S., \&Brodie, R. (2003). Measuring the quality of relationships in consumer services: An empirical study.European Journal of Marketing, 37(1/2),169-196.

[35]Hennig-Thurau, T., \& Klee, A. (1997). The impact of customer satisfaction and relationship quality on customer retention: A critical reassessment and model

development. Psychology and Marketing, 14(8), 737-764.

[36]Dwyer, R. F., \& Oh, S. (1987). Output sector munificence effects on the internal political economy of marketing channels. Journal of Marketing Research, 24(4), $347-358$.

[37] Jaworski, B. J., \&Kohli, A. K. (1993). Market orientation: Antecedents and consequences Journal of Marketing, 57(3), 53-70

[38] Ranaweera, C. and Prabhu, J. (2003), "the influence of satisfaction, trust and switching barriers on customer retention in a continuous purchasing setting", International journal of service Industry Mangement, VOI 14 No. 4, pp. 374-395

[39]Hart, C. and Johnson, M (1999), "Growing the trust relationship", journal of marketing Management, Vol. 8 No.1, pp. 8-19

[40] Stewart,K.,(1998),“An exploration of custome exit in retail banking. International journal of bank marketing Vol16,pp.6-14

[41] Well A and Morrison qualitative discussion of customer worry and normal obsession a comparative study Behavior research and therapy 32 867-870

[42] Holbrook, M. B. (1994). The nature of customer's value: An axiology of service in 


\section{IIMacrothink}

Journal of Sociological Research

ISSN 1948-5468

2014, Vol. 5, No. 1

consumption experience. In R. T. Rust,\& R. L. Oliver (Eds.), Service quality: New directions in theory and practice (pp. 21-71). Thousand Oaks, CA: Sage Publi-cations.

[43]Peterson, R. (1995). Relationship marketing and consumer. Journal of Academy of Marketing Science, 23(4), 278-281.doi:10.1177/009207039502300407, http://dx.doi.org/10.1177/009207039502300407

[44]Ganesan, Shankar (1994). Determinants of long term orientation in buyer-seller relationship.Journal of Marketing, 58,1-19. doi:10.2307/1252265, http://dx.doi.org/10.2307/1252265

[45] Kotler\& Keller 2008: Marketing Management (13th Edition) Philip Kotler Kevin Keller Publisher:Prentice Hall; 13 edition (March 6, 2008)

[46] Guenzi, P. and Pelloni, O. (2004) The Impact of Interpersonal Relationships on Customer Satisfaction and loyalty to the Service Provider, International Journal of Service Industry Management, 15(4), 365-84parg, S.G., N.B. Jones and J. van Staden. 2002. Artificial seed fromPinuspatulasomatic embryos. S. Afr. J. Bot. 68:234-238.

[47]

Rensburg, RS \& M Cant 2003. Public Relations: South African Perspectives SoutAfrica: Heinemann.

Rezai, Mahmoud (2009) "Effects of interpersonal communication on

satisfaction and loyalty of customers (parents) in a non-profit schools of high school in Tehran", MS Thesis, Tehran University

[49] Heidarzadeh, KambizHosseiniFirouzabadi, (2006) study of interpersonal communication and its impact on customer satisfaction and loyalty to the service provider, Journal of Marketing Management, Islamic Azad University, Tehran Science and Research. 
Seller

Relationships, Journal of Marketing. 51(Apr), 2, 11-27.

[51] Rauyruen, P., \& Miller, K. E. (2007). Relationship quality as a predictor of

B2B customer loyalty. Journal of Business Research, 60(1), 21-31

[52] Oliver, R.L., Rust, R., Varki, S., 1997. Customer delight: foundations,

findings and managerial insight. Journal of Retailing 73, 311-336.

Iqbal, U., Rizwan, M., Zafar, A., Khan, M. H., Usman, M. \& Iqbal, D. (2013) Determinants Uncovering the Brand Loyalty: A Signaling effect of Price on Quality Perception. Journal of Basic and Applied Scientific Research, 3(11), 212-221 